\title{
Kalosara Revitalization as an Ethno-Pedagogical Media in the Development of Character of Junior High School Students
}

\author{
Anwar $^{1}$, I Ketut Suardika ${ }^{2}$, Mursidin T. ${ }^{1}$, Abdul Rauf Suleiman ${ }^{3} \&$ Muhammad Syukur $^{4}$ \\ ${ }^{1}$ Department of History, Faculty of Education, University of Halu Oleo, Kendari, Indonesia \\ ${ }^{2}$ Department of Education, Faculty of Education, University of Halu Oleo, Kendari, Indonesia \\ ${ }^{3}$ Department of Aecheology, Faculty of Cultural Science, University of Halu Oleo, Kendari, Indonesia \\ ${ }^{4}$ Department Sociology of Education, Faculty of Social Science, Universitas Negeri Makassar, Indonesia \\ Correspondence: Anwar, Department of History, Faculty of Education, University of Halu Oleo, Kendari 93232, \\ Indonesia. Tel: 62-852-4152-9993. E-mail: anwarhapide@yahoo.com
}

Received: August 15, 2017

doi:10.5539/ies.v11n1p172
Accepted: September 22, 2017

Online Published: December 29, 2017

URL: https://doi.org/10.5539/ies.v11n1p172

\begin{abstract}
The aims of the research are (1) to identify types of character through kalosara revitalization as an ethno-pedagogical media in social sciences (IPS) learning at junior high school (SMP), (2) to develop strategy of kalosara revitalization as an ethno-pedagogical media in the development of characters of students, and (3) to develop a model of student character education through kalosara revitalization in IPS learning in SMP as an ethno-pedagogical media. The research is conducted through naturalistic approach. The research subjects are social science teachers at the junior high school, junior high school principals, and local public figures. Data collection is conducted at SMP Negeri 1 Wawotobi representing a heterogenous student group. Data was collected qualitatively using domain and taxonomy analysis models. Research result indicates that: (a) there are 74 values identified and distributed in 18 types of character that can be developed through kalosara revitalization as an ethno-pedagogical media in social sciences learning in junior high school, (b) kalosara revitalization strategy, as an ethno-pedagogical media in the development of characters, is conducted in form of integration in each theme and sub-theme in the syllabus of social sciences subject, (c) The character education development model through kalosara values as an ethno-pedagogical media indicates that there are three strengths of the model, i.e.: it elevates the local culture into national culture, it is a scientific model, and it is easy to understand and implement by teachers and students.
\end{abstract}

Keywords: revitalization, kalosara, ethno-pedagogy, value, character

\section{Introduction}

At present, there is a tendency of a decrease in the appreciation and implementation of cultural values and national integrity and identity among young generation. The decrease occurs due to the lack of integration of environmental culture of the students to their learning both at school and at their home and environment. Therefore, students seem to be uprooted from their cultural root. As consequences, junior high school children are vulnerable to negative behaviors and have attitude to try something new and if there is no good character education to control them, they can do contra-productive acts.

Negative behaviors of teenagers are not only occurred in the big cities but also in inland areas, especially in the remote areas that experience sudden change into open areas due to the exploitation of environment by mining and plantation companies controlled by and employed skilled people from outside of the area. As consequences, social jealousy occurs in local community showed through negative behaviors, such as vandalism of the facilities and infrastructures of the company and a clash with company's employees. On the other side, the business people and the employees from outside the area have less appreciation on local cultural values and even damage the local socio-cultural environment, thus, rejection arises among local community that bring conflict. On surface, the conflict seems to be economic in nature however it is actually due to the socio-cultural differences (Anwar, 2013).

Based on the phenomenon, real efforts are needed to strengthening the nationalism values and nation characters through the extraction and preservation of local wisdom values by means of formal and non-formal education. 
The strategy can be conducted easily through an ethno-pedagogical model education, which is a local wisdom-based education (Surya, 2011). In line with this, culturally, each tribe tries to give lesson to their generation in order to preserve their culture and to adjust with their environment. Therefore, a cultural continuum should present so that there will be a new embodiment added as well as released (Linton, 1984). Thus, according to Edwards (2012), training for teachers is needed to integrate content and pedagogy in learning. According to Peursen (1988) good individuals are expected to make their culture as a learning process to have a better life; in addition, learning process is a cultural transmission process (Tilaar, 2008).

The view is in line with the ethno-pedagogical study emphasizing on the ethnical aspect since it is relevant to overcome national character awareness problem. Klara (2015) explained that ethno-pedagogy is related to the background of certain ethnic.

Historically, ethno-pedagogy according to Tufekčić (2014) is started in the second part of the $20^{\text {th }}$ century and it was first written by GN Volkov in 1999, which is a science that study about upbringing, the real pedagogic view, and daily educational practices in the family and community.

The current internationalization and inclusivity of culture has brought important principles in guiding a change. McLoughlin (2006) offered pedagogical frame of inclusive culture that can be applied for online environment and suggested a study link of inclusive culture by using principle of constructive alignment with ethno-pedagogical approach.

The inheritance system of knowledge, values and skills in various ethnics is the form of ethno-pedagogy. For Tolaki people, their local wisdom is tied in the kalosara philosophy that has four functions, i.e.: (1) an idea, (2) a focus and integration of cultural elements, (3) a way of life, and (4) a unifier (Tarimana, 1989).

Tolaki people have no letters thus the values inheritance system is conducted orally. Nevertheless, they have their own way based on the educational principles that leaning on Kalsara as their educational philosophical view. The view stresses on the affective aspect that highly uphold the positive characters and presents in the daily life both symbolically or factually (Anwar, 2015a).

Based on the thought, a solution formula need to be found that based on local wisdom. Kalosara that culturally and historically always be a media in various problem-solving of Tolaki people needs to be revitalized as an educational media in form of ethno-pedagogy. The formulation is important to be done due to the development of contemporary context and it should be conducted through intercropping model in junior high school learning considering the students at this age are vulnerable to the development of attitude thus they need to be provided with local cultural-based character education through social engineering in form of teaching materials by modifying the function of kolasara in the learning without eliminating the sacred cultural values.

\section{Literature Review}

\subsection{Ethno-Pedagogic Concept}

Ethno-pedagogy is an education science related to an ethnic or nation (Kartadinata, 2014). In this case, education cannot be separated from the life philosophy of a nation or ethnic in form of local wisdom of students' environment. Ethno-pedagogy is an education based on community culture that should be preserved in order to progress and develop so it can achieve a superior life and living side by side with other countries in the world. Ethno-pedagogy is not only promoting superior fields in the communities based on their culture but also it should develop, repair, and change the code of conduct or mindset of the communities so they can explore various kinds of knowledge and develop a life with other communities while preserving their culture (Ernest, 1992).

According to Tufekčić (2017) the basic effort of ethno-pedagogy is to achieve harmony between individuals, social condition and natural environment. The harmonization of relationship in childhood implies the development and preservation of natural activities of the children without full control from the adults. The presence of ethno-pedagogy, according to Fahrutdinova (2016), is to overcome ethnic conflict that develops in the new socio-cultural environment, a study about interaction process in education environment and multi-ethnic education, and a national identity that occurs for ages, thus the actualization of ethno-pedagogical education is needed in this contemporary situation. Multicultural space in the new socio-cultural condition is achieved by learning the pedagogy of Russian in ethno-pedagogical journey.

According to Tufekčić (2014), Fahrutdinova (2016), the preservation and development of spiritual culture is unimaginable without an adequate and developed pedagogical practice. The focus of each pedagogical culture is a successful child care by considering the essence of upbringing. Everyone gives sample on the real and universal achievement related to one's upbringing. The specificity of pedagogical culture is proven in the 
parenting process where people collect spiritual wealth from generation to generation and change, improve, develop and enrich the pedagogical practices.

Pedagogical knowledge is closely related to the life philosophy, morality, and general knowledge. Through ethno-pedagogy, someone could witness a work and act of an educator as a craftsmen, singer and story teller, whom that have a concrete and practical ability. An important component of a saying is the lesson since it provides goals, tools, and methods of parenting. Through puzzles, someone could find a combination of influence on the understanding of children about the world with the intention of building intellectual education that aligned with all other aspects of personality formation. The role of song is to develop love and build esthetic and taste.

According to Brodovskaya et al. (2016), education conducted to students in their mother language could give contribution to the spiritual enhancement of non-Russian community and their adjustment with the Russian. Teachers should have the same nationality as their students and they are not only a trusted person but also have pedagogical education previous to their teaching, thus they could deliver Christian teachings to the foreigners in accordance with the religious concept, moral beliefs and their way of thinking.

How importance ethno-pedagogy is so a thought and effort of ethno-pedagogical training for teachers occurs that aimed to promote spiritual and moral education to the young generation, to increase teacher competence, and to identify the opportunity to use teaching system, tools, method and types of modern ethno-pedagogy. Ethno-pedagogical concept involves the achievement of a number of goals: preparing future teachers to work to strengthen and preserve progressive ethno-pedagogical tradition; forming an understanding of the goal of ethno-pedagogy; and developing the ability to use ethno-pedagogy in modern education system.

Tufekčić (2014) gave example in the traditional culture of daily Bosnian as a shelter for ethno-pedagogical practice. The practice is born in a concrete community and covers the whole life cycle from birth to death. Dneprov (2010) gave example of ethno-pedagogical heritage of native West Siberia that rich of shapes and materials that need to be restudied, reconstructed and implemented in modern condition. Various physical activities facilities, such as traditional games, health improvement methods, physical training for industry and economy, trading process, military campaign, and daily activities, provide all condition needed to form healthy and intelligent young generation. Khairullin (2017) also gave example ofthe integration motivation of Kazakhs on patriotic education of the youth into a system of the formation of professional competence of pre-service teachers.

The life condition and education system between the past and the present is very different; therefore a connecting line needs to be drawn between both. In this context, a process is needed to select important parts of the past to be integrated into the modern education system. The selection of integration content, according to Yachina et al. (2016), should include knowledge, ability and skill from the field of ethno-aesthetics, technology and scientific knowledge that able to give achievement continuity in ethnical values and scientific values in the school system to a subject of education. Content arrangement is conducted by considering age as an influencing factor for harmonious personality development in the field of technology, professional, emotional, spiritual, and aesthetics.

According to Masyitoh (2015), ethno-pedagogy-based character educational model had positive and significant influence on student character. Moreover, homogenous school environment was more dominating the strong character compare to heterogeneous school environment.

Arthur (2004) stated that one of the most effective models in the history of ethno-musicology was Alan Merriam model that base on the concept, behavior, and sound related to the music. Ethno-pedagogical model consists of: actor, analyst, reader, and guide. In this model, everyone involved in the pedagogical process is influenced by others. Just like a ring (circular waves) formed by a rock that fall into a water pool, one action creates other actions. In the end, each part of the model influences the interpretation of pedagogical process and how the musical culture is built.

Khairullin (2017) stated that for the effectiveness of the use of tradition as patriotic media, it is useful for the pre-service teachers to use a lecture method on the tradition of physical development of a man that reflects the patriotic education to the youth.

Ethno-pedagogic model is not aimed to educate the community to merely learn and preserve their culture and disrespect other cultures. On the contrary, it educate the community to explore knowledge, skill, and value based on their culture as well as support the shared order of life, which is the basic to achieve democratic life (Kartadinata, 2014). Education through local wisdom adaptation, including reinterpretation of values containing in a number of proverbs with the contemporary condition, could be an instrument to solve social problems since 
mostly social problems come from local issues.

There are some characteristics of local wisdom, i.e.: (a) it is based on experience; (b) it is tested after being used for centuries; (c) it can be adapted with; (d) it is unified in the daily practice of the community; (e) it is common to be conducted by an individual or community as a whole; (f) it is dynamic in nature and simultaneously change; and (g) it is strongly related to a belief system (Alwasilah, 2008).

Local wisdom can be a synergic vehicle between modernization goals and local superiority preservation. For Tolaki people, local wisdom of kalosara can function as ethno-pedagogical media.

Ethno-pedagogy is defined as to give new understanding that adjusted to the prevailing cultural values in local environment. A novelty can be easily accepted if it contains values that in line with the local values since education through ethno-pedagogical approach views local knowledge as the source of innovation and skills that can be empowered (Surya, 2011).

Ethno-pedagogy is closely related to multicultural education. It views knowledge and local wisdom as source of innovation and continued with multicultural education that empower innovation thus it can contribute positive input for other social groups and national cultures.

\subsection{Concept and Function of Kalosara}

Kalosaraconsisted of three parts: (a) kalo means a coil of three circular rattans, (b) white fiber as a layer, and (c) siwoleuwa means a woven from palm leaves in rectangular shape. Stand alone, the three containers have no meaning and customary function unless they unite in an order with a structure as the very bottom cover in form of simoleuwa and coated with white fiber and above both containers a kalo is put (Anwar, 2015a).

An event where someone, who are embarrassing by the impolite behavior of others toward him/her in public, gives strong reaction in form of persecution threat against those people to defend him/her pride. In this situation, a third party emerges to perform kalosara between the two parties who threatening each other. The event will automatically stop with both parties forgive each other since they consider kalosara to be identic to an expression of: "don't, ask forgiveness and mercy, you, him/her, and me are one, one in three and three in one." Torturing him/her means that you are torturing yourself and torturing me as well as all of us (Anwar, 2015a). Through the performance of kalosara in that situation, both parties make a peace. If one of them or both of them reject the kalosara, they are cursed and should be exiled from Tolaki people or receive punishment based on the prevailing customary provisions.

According to Tarimana (1989), kalosara for Tolaki tribe is a focus that integrates elements in their culture. It has four functions: (a) Kalo as an idea, (b) Kaloas a focus, (c) Kalo as a way of life, and (d) Kalo as a unifier and solution.

Kalosara, anthropologically, is the focus of Taloki culture. Linton (1984) called it a cultural interest or social interest, which is a complex of cultural elements that seems to be liked by the community thus it looks like dominating the whole life of the related community (Koentjaraningrat, 1981).

Ethno-pedagogy based on the values of Javanese tradition has been covered by Ki HajarDewantoro. It consists of three aspects: (a) ingngarsa sung tuladha, (b) ingmadyamangunkarsa, and (c) tut wurihandayani (Dewantara, 1977). The educational concept is adopted into the national educational value in Indonesia (Surya, 2011). For Bugis people, the ethno-pedagogy is based on the value initially developed by a scholar named La Mellong who also served as the advisor of the King of Bone the $6^{\text {th }}$, La Uliyo, who ruled in 1543-1568 (Ali, 1986). The slogan is Rioloinapatiroang= the front gives example/guide; Ritengngainasiraga-raga $=$ the middle gives spirit; Rimunrinapponglop $i=$ at the back gives encouragement.

In Tolaki people, the educational philosophy is rooted from a saying: Inae konasara ie pinesara; inae liasara ie pinekasara $=$ who know the custom will be respected; who violate the custom will be treated rudely (Tamburaka, 2004). Conceptually, Cobern (2008) stated the importance of cultural aspect of learning science.

Empirically, ethno-pedagogical model utilizing local wisdom has been proven by a research result from Hermani (2012) that facilitate the chemistry learning in senior high schools in West Java, such as batik culture in Garut and ruwatan (a ceremony conducted to get rid of bad things) keris in Cirebon. It is also in line with a research by Wahyudi (2003) on local cultural-based natural sciences learning. Similar research is also conducted by Wuryandani (2013) on the integration of local wisdom values in learning to cultivate nationalism. The empirical findings support the research on the importance of revitalization of kalosara as a local wisdom in the development of character through social sciences learning in junior high school. 


\subsection{Character Education}

A research from Harvard University stated that the success of an individual is not merely determined by his/her knowledge and cognition (hard skills) but it is more to the ability in managing self and other (soft skills). The research revealed that success is 20 percent hard skills and 80 percent soft skills. Soft skills are formed through character education to students (Anwar, 2014).

According to Raharja (2010), character education is an effort to create noble character. Character education should be implemented in the educational pattern given to students (Benninga, 2006). It should be formulated in a curriculum and implemented in learning (Koesoema, 2007). Therefore, superior generation of Indonesia will be born from character education system (Anwar, 2014).

The Ministry of Education formulates 18 value items as the priority of refinement to the junior high school students: religious, honest, tolerance, disciplines, hard work, creative, independent, democratic, curiosity, nationalism, patriotism, respect achievement, friendly, love peace, love reading, environmental awareness, social awareness, and responsible (Anonym, 2012).

According to the result of a research by Mislia (2016), there are some strategies to be conducted to shape the characteristic of students at SMPN 1 Maros: intervention, example, habituation, strengthening, mentoring, and the involvement of other parties. Intervention strategy aims to cultivate certain character or change the character of students closer to certain expected characters. Example strategy is a good example for students in the daily life. Students tend to imitate their teacher both good and bad.

Due to the importance of character education in form of example, parents and teachers should develop positive characters so they can be transformed to the young generation in form of deeds and learning.

\section{Research Method}

The research was conducted in Konawe Regency area, which is the concentration area of Tolaki Tribe settlement and they still maintain kalosara culture in their life. The location selection was aimed to develop and preserve the local culture that tended to be forgotten by the young generation. On the other hand, they have inheritance tradition of values through their cultural philosophy in form kalosara. Therefore, the research was conducted at SMP Negeri 1 Wawotobi and SMP Negeri 2 Konawe. The research subjects were social sciences teacher in both schools of 8 people, the principals of both school, local public figures, and students at eight grade in both schools and in each school one study group was chosen as trial subject.

Data collection was conducted through observation (participative and structured), in-depth interview and focused discussion. Data validation techniques used were: (a) triangulation method, (b) data source triangulation, (c) intensive observation and (d) negative case analysis. Data analysis was conducted through qualitative model of domain analysis and taxonomy (Spradley, 1980).

\section{Result}

\subsection{Types of the Developed Characters}

The research finding indicates that there were 74 characters distributed in 18 values sourced from the culture of Tolaki Ethnic Groups. As stated by Tarimana (1989) that kalosara is the focus that could integrate the existing elements of Tolaki culture. Therefore, in the research, all character values developed from Tolaki culture were called as character values of Kalosara.

Table 1. Types of character from the developed kalosara

\begin{tabular}{lccc}
\hline No & Value & Number of Character & Description \\
\hline 1 & Religious & 2 & \\
2 & Honest & 5 & \\
3 & Tolerance & 3 & \\
4 & Disciplines & 2 & \\
5 & Hard work & 5 & \\
6 & Creative & 9 & \\
7 & Independent & 5 & \\
8 & Democratic & 6 \\
9 & Curiosity & 2 \\
10 & Nationalism & 5 \\
11 & Patriotism & 3 \\
12 & Respect achievement & 4 \\
\hline
\end{tabular}




\begin{tabular}{ccc}
\hline 13 & Friendly & 2 \\
14 & Love peace & 1 \\
15 & Love reading & 2 \\
16 & Environmental awareness & 4 \\
17 & Social awareness & 9 \\
18 & Responsible & 5 \\
& Total & 74 \\
\hline
\end{tabular}

Source: Research Result, Processed, 2017.

The values and characters were the essence of Tolaki culture identified in the research. One interesting result was the nine creative characters found in the research. It indicates that the ancestors of Tolaki ethnic group had put creative foundation to be used in the development of human resources since the creative value was an important value for individual or group wanted to progress and develop. Another predominate value was social awareness. The symptom proves that Tolaki people have been provided with high social solidarity attitude and it maintained in the daily life up to present. The social solidarity character value made various heavy jobs could be overcome since everyone will do it together. If an individual or group tried to avoid the attitude, they would be given social sanction inform of isolation in the social life.

The democratic value was also quite predominating and the phenomenon was in line with the social attitude. Therefore, all problems in the community were solved through deliberation (musyawarah), such as medulu (help each other).

\subsection{Strategy of Kalosara Revitalization as an Ethno-Pedagogic Media}

Revitalization strategy was started with discussion with Tolaki public figures in terms of asking permission for the implementation of kalosara revitalization in broader context. The public figures welcomed the plan as stated by M. SyarifTabara (Interview, April 11, 2017) that the inheritance of cultural values to young generation is needed so that the noble values of Tolaki people would not be vanished. Revitalization was defined as an exploration of the existing values in kalosara by maintaining the originality of the goods and their attached meaning.

Revitalization is defined as a learning in formal educational institution since according to the statement by Mardin (Interview, April 11, 2017) that our students at SMP Negeri 2 Konawe gave no respect if they walked in front of the teacher; therefore character learning is needed through the cultivation of ancestral cultural values, such as an expression of nggomiu (excuse me sir) used when talking in front of older or respected people.

Furthermore on the need of the preservation and development of Kalosara as the focus of Tolaki culture was stated by CecepSupriaYudowono (Interview, April 11, 2017), among others, that in addition to integration in the learning of character values in Tolaki culture, documentation is also needed in form of book and it is jointly written by education practitioners, humanist and academics to facilitate the distribution and the adoption by students. In addition, if there was no effort for the writing, the cultural noble values of the nation in Tolaki people could be eroded, eventually.

Empirically, students in both schools were dominated by parents from Tolaki ethnic groups and there were also students who are not from the ethnic group. Both student groups should understand the noble values in the Tolaki culture since they had to have basic noble culture of their origin in the daily intercourses and activities. The condition is important so that children have cultural footing of politeness and discipline since childhood thus they will bring the culture in their association to a wider life.

In the effort to facilitate the integration of noble values of positive characters from Tolaki culture, the relevance of each main subject in the syllabus to Tolaki culture, which was the description of kalosara, needed to be found. Following are the example of integration model in two sub-themes. 
Table 2. The integration model of character from kalosara in social sciences learning in SMP; Grade VII

\begin{tabular}{|c|c|c|c|c|c|}
\hline No & Theme & Sub-theme & Material & Value & Character \\
\hline 1 & $\begin{array}{l}\text { Theme 1: the } \\
\text { natural } \\
\text { condition and } \\
\text { activities of } \\
\text { Indonesian } \\
\text { People }\end{array}$ & $\begin{array}{l}\text { Sub-theme: } \\
\text { The location of the } \\
\text { territory and its } \\
\text { influence on the } \\
\text { natural condition of } \\
\text { Indonesia }\end{array}$ & $\begin{array}{l}\text { The location of the } \\
\text { territory and its } \\
\text { influence on the } \\
\text { natural condition of } \\
\text { Indonesia }\end{array}$ & Creative & $\begin{array}{c}\text { Morinimbu'umbundimona } \\
\text { pambu'undawaro: } \\
\text { As cold as banana tree, as } \\
\text { cool as sago tree / } \\
\text { prosperity and welfare }\end{array}$ \\
\hline 2 & $\begin{array}{l}\text { Theme 2: } \\
\text { The condition of } \\
\text { Indonesian } \\
\text { people }\end{array}$ & $\begin{array}{l}\text { Sub-theme A: the } \\
\text { Origin of } \\
\text { Indonesian people }\end{array}$ & $\begin{array}{l}\text { Material: The Origin } \\
\text { of Indonesian people }\end{array}$ & Patriotism & $\begin{array}{l}\text { Taaehetinua-tuay, and } \\
\text { Ni-are-are: an invitation to } \\
\text { always be proud as a part } \\
\text { of Tolaki people. }\end{array}$ \\
\hline
\end{tabular}

Source: Field data, processed, 2017.

Strategy of kalosara revitalization as an ethno-pedagogic media was something to enrich the materials of teachers as well as to facilitate teachers to implement contextual learning. Teaching material is generally in form of oral tradition, such as: onango (fairy tale), taenango (folklore), sua-sua (poem), singguru (puzzles), susua (song), livelihood system, and lifecycle ceremony. All of them contained relevant positive values to be developed as cultural spirit for the teenagers.

The teaching materials were intended for education not only to form an intelligent Indonesian man but also in order for them to be noble so that generation with characters based on the noble values of Indonesia will be born. It is also expected that it could develop the surrounding community in various life aspects.

\subsection{The Development Model of Kalosara Revitalization as an Ethno-Pedagogical Media}

The development model of kalosara revitalization in social sciences learning in junior high school was conducted in form of joint formulation between researcher team and social science teachers at the research subject schools. There were three main components of learning tools developed by teachers: Lesson Plan, learning materials and learning media.

Local content was developed through stages of: (a) analysis of the context of socio-cultural environment; (b) identification of local content, and (c) conceptual validation of local content in forms of study materials on the superiority and local wisdom of Konawe area, which is the implementation of the cultural values of Tolaki tied in kalosara.

The three dimensions of competence expected from the junior high school graduates were contained in the local content of revitalized kalosara in form of integration in social sciences learning. The process of model formulation and validation involved public figures and social science teachers at the junior high schools. The process was in form of conceptual validation through a practitioners test and workshop.

The research result indicates that there were three strengths of the development model of the integration of character values from Tolaki culture into social sciences learning in junior high school, which were: (a) elevate the local culture into the nation's culture, (b) it is a scientific model, and (c) it is easy to understand and implement by the students. The findings are in line with the state recognition of three Tolaki cultures as the non-objects cultural inheritance of Indonesia through an establishment by the Minister of Education and Culture of the Republic of Indonesia. The three cultures were Kalosara, Lulo and Mosehe. The establishment was related to the existence of the three cultures in the community.

Of the 10 subjects, all of them stated an agreement of integrating the values of Tolaki culture into social sciences learning. There were five reasons for the readiness of the teachers to integrate the culture into the learning, which were: (a) for cultural preservation, (b) to accustom the students to love the culture more, (c) the values of Tolaki culture is relevant to the material of social sciences learning, (d) to add reference of national culture originated from local culture, and (e) to widening the students' knowledge beyond the national and international cultures with knowledge on local culture in their surrounding area.

The weaknesses of the development model of the integration of character values from Tolaki culture into the social sciences learning at SMP were: there were no books available for teaching materials, less knowledge of teachers on Tolaki culture, and less initial knowledge of students on Kalosara values. 
The research subjects reminded of the need of documentation for Tolaki cultural values so they could be used as learning materials for teachers as well as students. The research result found that there were many teachers with lack of comprehension on Tolaki cultural values, thus it was difficult to integrate it into the school learning. The teachers expected learning materials in form of books containing the character values of Tolaki culture as well as media that become a link between traditional media and modern media in form of audio visual media, such as ritual activities video. The teachers realized the need of contextual learning based on social and natural environment of the students.

The data implies that the teachers realized the scarcity of learning materials; therefore, it was right to use method that involved students actively to explore information individually or in group. Methods developed were: persuasion, sample, order, explanation, exercise, advice, instruction, warning, will, threats and punishment. The result of discussion with the teachers stated that they had conducted some adjustments, such as discussion method, study tour, assignment and question and answer were appropriate to be used. Theoretically, the finding was felicitous since the learning materials are exist in the middle of the community and natural environment of the students. Therefore, through the three methods, students are asked to explore the environment in form of critical thought so it will give impact on the occurrence of environmental and social awareness of the students. The appropriate media used are map, picture or photo, the original objects in certain situation.

There are seven suggestions from teachers on the implementation of model of integration of character values of kolasa into social sciences learning: (1) more literature on Tolaki culture is needed, (2) the character values of Tolaki culture need to be implemented in school to give insight to the students, (3) training for teachers on Tolaki culture, (4) the involvement of teachers in Local/Tolaki Culture Seminar, (5) teachers give more assignments to students so that parents are encouraged to learn Tolaki culture, (6) teachers need to use good and correct vocabulary so it can be copied by the students, and (7) application in a curriculum as an independent local content subject.

The trial result indicates that student at SMP Neger 2 Konawe located in the hinterland had acceptance level of 42 characters $(56.67 \%)$, which was higher than those students at SMP Negeri 1 Wawatobi located in the urban area of 39 characters $(52.70 \%)$. Both were distributed in 12 similar values as indicated in the following Table 3 .

Table 3. Types of Characters Developed by Junior High School (SMP) Students

\begin{tabular}{llcc}
\hline \multirow{2}{*}{ No } & Value & \multicolumn{2}{c}{ Numbers of Characters } \\
\cline { 2 - 4 } & & 2 & 2 \\
2 & Religious & 5 & 4 \\
2 & Honest & 3 & 3 \\
3 & Tolerance & 0 & 0 \\
4 & Disciplines & 0 & 0 \\
5 & Hard work & 0 & 0 \\
6 & Creative & 0 & 0 \\
7 & Independent & 4 & 4 \\
8 & Democratic & 2 & 2 \\
9 & Curiosity & 4 & 4 \\
10 & Nationalism & 2 & 1 \\
11 & Patriotism & 3 & 3 \\
12 & Respect achievement & 2 & 2 \\
13 & Friendly & 1 & 1 \\
14 & Love peace & 0 & 0 \\
15 & Love reading & 4 & 3 \\
16 & Environmental awareness & 6 & 6 \\
17 & Social awareness & 4 & 4 \\
18 & Responsible & & $39(52.70 \%)$ \\
& Total & $42(56.76 \%)$ & \\
\hline
\end{tabular}

Source: Field data, processed, 2017.

The finding indicates that the development of characters of students in the hinterland area (homogenous) tended to be better than those students in the urban area (heterogeneous). The data gave information that 
ethno-pedagogical values of Konawe people were high thus it needed to be preserved and developed in education process for teenagers both through formal and informal education. Ethno-pedagogical system developed in kalosara culture needed to be revitalized according to the dynamic in the community life without changing the essential meaning contained.

\section{Discussion}

The finding of the research that developed kalosara culture as a local content according to Chapter 4 of Permendikbud (the Regulation of Minister of Education and Culture) No. 79/2014, stated that: (a) local content is a cultural art, (b) learning content related to local content is in form of learning materials on the superiority and local wisdom, (c) learning content related to local content is integrated in social sciences subject.

The finding had three dimensions: knowledge, attitude and skills (Permendikbud No. 20/2016). In attitude dimension, the competence of the expected graduates for SMP students is for them to have behavior that reflects the attitudes of: (a) faithful and cautious to the One Almighty God; (b) having character, honest, and care, (c) responsible, (d) lifelong true learner, and (e) physically and mentally healthy according to child development in the environment of family, school, community and the surrounding natural environment, state, nation, and regional area.

The research result strengthen the research finding of Maryam (2015, p. 59) stated that the use of oral tradition in the learning of social sciences (IPS) subject could increase teaching effectiveness of the teachers and could improve positive character of the students, such as: discipline, friendly, democratic, responsible, and creative, and to facilitate teachers to control the learning implementation. For students, it is a training process in developing idea and forming positive communication way in the future.

It is also in line with a research result by Asban (2016) stated that the implementation of local history in form of oral tradition in history learning could increase teaching effectiveness of the teachers and increase positive character of the students. The phenomenon is supported by Anas's (2011) statement that character education is intended to improve the quality of the implementation and educational outcomes at school that lead to the achievement of character and moral building of the students as a whole, integrated and sustainable.

The research finding is also in line with the mandate of chapter 3 of Law No. 20/2003 on the development of learners potential to have intelligence, personality and noble characters. According to the mandate in the goals of national education, education units should focus more on the development of learner potential related to the characters. It proven that education process should have orientation on behavioral aspects. Regarding the finding, Tatarko (2017) found that ethnic diversity in Russia was positively related to the informal friendliness and has no influence on the community trust and organizational life of the community.

The research finding is an effort to train teachers in developing pedagogic competence and their professionalism rooted from the culture. Tolaki, especially the obedience to the norm, should be taught to the students as stated by Fahrutdinova (2016) that in this context, training for teacher regarding the ethno-pedagogical development process in modern school is needed including moral character building, mental development and the love of culture. Arsaliev (2017) formalized the ethno-pedagogical process into technology thus it allows rational, objective and valuable disclosures. It made education experience belong to most of the teachers thus it allowed moving further in solving problems of character building and the development of ethno-pedagogical theories.

Related to learning method, the research result strengthens the opinion of Fahrutdinova (2016) that added the need of the selection of a relevant method such as: persuasion, sample, order, explanation, exercise, spell, vow, request, advice, instruction, approval, warning, agreement, remorse, repentance, preaching, will, threats and punishment. According to Yachina et al. (2016), to give innovative orientation of integrative content selection, alternative system needs to be studied in form of methodology guidance to select content and method, the content of education technology as a didactic mean to enrich intellectual, spiritual quality and the development of technical and artistic creativities.

Kalosara revitalization sourced from oral tradition as the research finding is strengthened by the opinion of Fahrutdinova (2016), Tufekčić (2014), Dagbaeva (2014), Khairullin (2017) that ethno-pedagogical education facility is generally used verbal creation style, such as: rhymes, proverbs, puzzles, fairy tales, legends, myths, proverbs, songs, stories, traditions, traditional games, customs, epics, and poetry.

According to Dagbaeva (2014), to date, the pedagogical experience of the people was less used in the practice of modern education institutions. Currently, it is necessary to allocate the basic value of the people experience on children socialization that appropriate to the current condition in the implementation of the practice of modern education institutions. 
Tufekčić (2017), Yachina et al. (2016), Tufekčić (2014) stated that in every life situation, education is proven to influence the creation of harmonious relationship between individual and the community.

Saragih (2017) stated that the presence of local cultural context in learning supported the meaningful learning process as expected. In addition, for Tolaki people in Konawe area, there are many non-objects and objects of cultural heritage that should be socialized and developed so that they could become the national culture and that contain character values.

Trial finding stated that the adoption process of student character from SMP with homogenous background was better than those from SMP with heterogeneous background. The finding supports the research result of Masyitoh (2015) that ethno-pedagogy-based character education model had positive and significant influence on student character. Moreover, homogenous school environment dominating the strong characters than those of heterogeneous school environment.

Finally, it can be stated that kalosara culture, which is an oral tradition, needed to be revitalized through ethno-pedagogy since it is needed in the practice of modern education.

\section{Conclusion}

The research identified 74 types of positive characters that can be developed through kalosara revitalization as an ethno-pedagogical media in social sciences learning in junior high school.

Strategy of kalosara revitalization in the development of characters was conducted in form of integration in each theme and sub-theme in the syllabus of social sciences subject. In each sub-theme, at least one character developed from cultural values which are the operationalization of kalosara in the life of Tolaki people. Teaching material was generally sourced from oral tradition passed through ethno-pedagogical process with varied learning methods according to the situation and condition.

The development model of character education through kalosara values as an ethno-pedagogical media was started with joint formulation between research teams and social sciences teachers: there were three main components in the learning media, which were Lesson Plan, learning materials and learning media. Local content was developed through stages: analysis of socio-cultural environmental context, identification of local content, and conceptual validation. The research result indicates that the character building of students in the hinterland area (homogenous) tended to be better than those students in the rural areas (heterogeneous). The data gives information that ethno-pedagogical values of Konawe people were still high thus they need to be preserved and developed in the education process of the teenagers.

\section{References}

Ali, A. M. (1986). Bone Selayang Pandang. Watampone: Damai.

Alwasilah, A. C. (2008). Tujuh AyatE tnopedagogi. Artikeldalam Pikiran Rakyat Bandung, 23 Januari 2008.

Anas, Z. (2011). PedomanP elaksanaan Pendidikan Karakter. Jakarta: Kemendiknas.

Anonim. (2012). Kurikulum Pendidikan Karakter. Retrieved from http://www.pendidikankarakter.com/ kurikulum-pendidikan-karakter/

Anwar, Ahiri, J., \& Haq, P. (2014). Konsep Dasarllmu Pendidikan. Bandung: Alfabeta.

Anwar, Amiruddin, Suardika, I. K., Sartono, \& Peribadi. (2015a). An Analysis of Kalosara Function as Ethnopedagogic Media in Nation Character-Building in South East Sulawesi. International Research Journal of Emerging Trends in Multidisciplinary, 1(9).

Anwar, Rosdin, A., Mosoffa, M., \& Akbar, M. N. (2015b). Pendidikan Multikultural Berbasis Kearifan Lokal. Jakarta: Balitbang Kemendikbud.

Anwar. (2013). Konflik Sara di Wilayah Pertambangan (Kasus Sulawesi Tenggara). Makalah Disajikan Dalam Kongres Kebudayaan Indonesia di Yogyakarta, Tanggal 8-11 Oktober 2013.

Arsaliev, S. (2017). Ethnopedagogical Technologies: Best Approaches and Practices. Recent Patents on Computer Science, 10(4), 173-184. https://doi.org/10.2174/2213275908666151008212858

Arthur, S. K. (2004). Sound of Praise: Reflexive Ethnopedagogy and Two Gospel Choirs in Tallahassee, Florida. Electronic Theses, Treatises and Dissertations, The Graduate School. Florida State University Libraries. Retrieved from http://diginole.lib.fsu.edu/islandora/object/fsu\%3A168076/datastream/PDF/view

Asban. (2016). Penerapan Metode Diskusidengan Menggunakan Tradisi Lisan Dalam Mengembangkan Karakter Positif Siswapada Pembelajaran Sejarah SMAN 03 Bombana. Kendari: Program Pascasarjana 
Universitas Halu Oleo.

Benninga, J. S. (2006). Character and Academic: What Good School Do. Dalam Phi Delta Kappa. EdisiFebruari (Hal. 448-453).

Brodovskaya, L. N., \& Buravleva, V. V. (2016). The Role of Ilminsky's Ethno-Pedagogical System In Achieving "Stable Convergence" of The Peoples of The Multinational Volga-Ural Region Of Russia. Man In India, 96(3), 795-802.

Cobern, W. W., \& Aikenhead, G. S. (2008). Cultural Aspects of Learning Science. In B. J. Fraser, \& K. G. Tobin (Eds.), International Handbook of Science Education (pp. 39-52). Kluwer Academic Publisher.

Dagbaeva, S. B. (2014). Ethnopedagogical Aspects of Modern Students Socialization. Psychological Science and Education, 6(4), 24-32. Retrieved from http://psyjournals.ru/en/psyedu_ej/2014/n4/73595.shtml

Dewantara, K. H. (1977). Pendidikan. Jogjakarta: Tamansiswa.

Dneprov, S. A., \& Krasilnikov, V. P. (2010). Ethnopedagogical Heritage of the Development of Physical Activity in the Preservation of the Indigenous Population of West Siberia. Revista Pedagógica ADAL, 20, 35-37. Retrieved from https://dialnet.unirioja.es/servlet/articulo?codigo $=4013744$

Edwards, N. T. (2012). Integrating Content and Pedagogy: A Cultural Journey. Action in Teacher Education, $19(2)$.

Ernest, J. (1992). From Mysteries to Histories: Cultural Pedagogy in Frances E. W. Harper's Iola Leroy. American Literature, 64(3), 497-518. https://doi.org/10.2307/2927749

Fahrutdinova, G. Z. (2016). Ethno-Pedagogical Factor of Polycultural Training. International Journal of Environmental \& Science Education, 2016, 11(6), 1185-1193.

Hamida, Sameh, B., Maaloul, Alia, \& Hamida, S. B. (2016). The Pedagogical Innovation Serving Technological Education. Creative Education, 7, 20-31. https://doi.org/10.4236/ce.2016.71003

Kartadinata, S. (2014). Politik Jati Diri. Bandung: UPI Press.

Khairullin, I. T., Bimakhanov, T. D., Murzabekov, M. K. (2017). Ethno-Pedagogical Training As A Tool Of Patriotic Education Of Pre-Service Teachers. III International Forum on Teacher Education. The European Proceedings of Social \& Behavioural Sciences. https://doi.org/10.15405/epsbs.2017.08.02.43

Klara, K., Ortayev, B., Kaliyeva, S., Utaliyeva, R., \& Jonissova, G. (2015). Ethnic Pedagogy as an Integrative, Developing Branch of Pedagogy. Mediterranean Journal of Social Sciences, 6(1), 612, https://doi.org/10.5901/mjss.2015.v6n1s1p612

Koentjaraningrat. (1981). Kebudayaan Mentalitas dan Pembangunan. Jakarta: Gramedia.

Koesoema, D. K. (2007). Pendidikan Karakter. Jakarta: Grasindo.

Linton, R. (1984). The Study of Man (Antropologi Suatu Penyelidikan Manusia). Diterjemahkanoleh Firmansyah. Bandung: Jemmars.

Maryam. (2015). Pengembangan Karakter Positif Siswa Melalui Pembelajaran IPS dengan Memanfaatkan Tradisi Lisan di SMP Negeri 5 Kendari. Kendari: Tesis S2 PPs UniversitasHalu Oleo.

Masyitoh, I S. (2015). Model Habituasi Pendidikan Karakter Berbasis Etnopedagogik Disertasi Doktor Pada Sekolah Pascasarjana Universitas Pendidikan Indonesia. Bandung.

McLoughlin, C. (2006). Inclusivity and alignment: Principles of Pedagogy, Task and Assessment Design for Effective Cross-Cultural Online Learning. Distance Education, 22(1).

Mislia, Mahmud, A., \& Manda, D. (2016). The Implementation of Character Education through Scout Activities. International Education Studies, 9(6), 130-. https://doi.org/10.5539/ies.v9n6p130

Raharja, S B. (2010). Pendidikan Karaktersebagai Upaya Menciptakan Akhlak Mulia. Dalam Jurnal Pendidikandan Kebudayaan, 1(3), 229-238.

Sabirova, D. (2015). Ethnocultural Component of Foreign-Language Education: Innovative Mode. Mediterranean Journal of Social Sciences, 6(3), 362-367. https://doi.org/10.5901/mjss.2015.v6n3s1p362

Saragih, S., Napitupulu, E. E., \& Fauzi, A. (2017). Developing Learning Model Based on Local Culture and Instrument for Mathematical Higher Order Thinking Ability. International Education Studies, 10(6), 114-122. https://doi.org/10.5539/ies.v10n6p114 
Spradley, J. P. (1980). Participant Observation. New York: Holt, Reneihart and Winston.

Surya, P. (2011). Kepemimpinan Etnopedagogi di Sekolah. Dalam Majalah Ilmiah Dinamika. UNY, Edisi Mei 2011.

Tamburaka, R. E. (2004). Sejarah Sulawesi Tenggara dan 40 TahunSultra Membangun. Kendari: Unhalu Press.

Tarimana, A. (1989). Kebudayaan Tolaki. Jakarta: BalaiPustaka.

Tatarko, A., Mironova, A., \& van de Vijver, F. J. R. (2017). Ethnic Diversity and Social Capital in the Russian Context. Journal of Cross-Cultural Psychology, 48(4). https://doi.org/10.1177/0022022117692099

Tilaar, H. A. R. (2008). Peran Pendidikansebagai proses Pembudayaan. DalamIndustri Budaya-Budaya Industri. Jakarta: Kementerian Kebudayaan dan Pariwisata RI.

Tufekčić, A. (2014). The Ethnopedagogical Mosaic of Bosnia and Herzegovina. Spirit of Bosnia: An International, Interdiciplinary, Bilingual, Online Journal. Retrieved from http://www.spiritofbosnia.org/volume-9-no-3-2014july/the-ethno-pedagogical-mosaic-of-bosnia-and-herzeg ovina/

Tufekčić, A. (2017). The Early Childhood as an Ethnopedagogical Phenomenon. World Assembly and International Conference. Retrieved from http://programme.exordo.com/omep2017/delegates/presentation/ $115 /$

Van-Peursen, C. A. (1988). Strategi Kebudayaan. Yogyakarta: Kanisius.

Wahyudi. (2003). Tinjauan Aspek Budayapada Pembelajaran IPA: Pentingnya Kurikulum IPA Berbasis Kebudayaan Lokal. Dalam Jurnal Pendidikan dan Kebudayaan. No. 040 Januari 2003.

Yachina, N. P., Petrova, T. N., Kharitonov, M. G., Nikitin, G. A., \& Zhumataeva. (2016). The Method of the Content Selection for Formation of Technological Culture among Students Based on Ethnological Values. Mathematics Education, 11(1), 211-219.

\section{Copyrights}

Copyright for this article is retained by the author(s), with first publication rights granted to the journal.

This is an open-access article distributed under the terms and conditions of the Creative Commons Attribution license (http://creativecommons.org/licenses/by/4.0/). 